\title{
Battle for a Colombian Park
}

\author{
Richard A. Meganck
}

In 1972 the Tayrona National Park, on Colombia's Caribbean coast, was suddenly threatened with a multi-million-dollar tourist complex to be built within the park boundaries. But Colombians in thousands objected to the plan-over 50,000 signed a petition to the Government. Eventually, in 1976, a presidential decree permanently excluded the proposed tourist development from Tayrona, a victory for conservation that the author believes could have resounding effects in Latin America.

Tayrona National Park on the north coast of Colombia includes representative ecosystems from the sea coast, through tropical thorn forest, to upland humid forests. The park comprises 12,000 hectares plus some 3000 hectares of the Caribbean Sea and its bottomlands, with a coastline broken by many pristine bays and coves and white sand beaches separated by truncated headlands. Moreover, Tayrona adjoins the Sierra Nevada National Park which includes the highest peaks in Colombia, and between them the two contiguous parks protect everything from the Caribbean coast to the glaciers of Cristobal Colon Peak, $5824 \mathrm{~m}(19,100 \mathrm{ft})$ high. This is one of the few places in the world where the opportunity to preserve a complete transect from the mountains to the sea exists.

The park includes a large part of shallow continental shelf and this is vital, for here are the submarine praderas (associations mainly of Thalassia testudinum, a plant of the Frogbit Family) which provide food for the five marine turtle species that nest on Tayrona's beaches: the green Chelonia mydas, hawksbill Eretmochelys imbricata, loggerhead Caretta caretta, olive ridley Lepidochelys olivacea, and leathery Dermochelys coriacea. ${ }^{16}$ This relatively shallow continental shelf also has coral reefs, and within the park areas are found more than 50 of the estimated 72 coral species of tropical fish in the Caribbean Sea, ${ }^{1}$ the majority in the Concha, Cinto, Chengue, Gairaca, Nenguange and

\begin{tabular}{|c|c|}
\hline & Archeological Site Pueblito \\
\hline 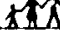 & Visitors Center \\
\hline & Biological Field Station \\
\hline & Park Limit \\
\hline & Highway \\
\hline$\hat{0}$ & Administration Building \\
\hline & Panger Station \\
\hline
\end{tabular}
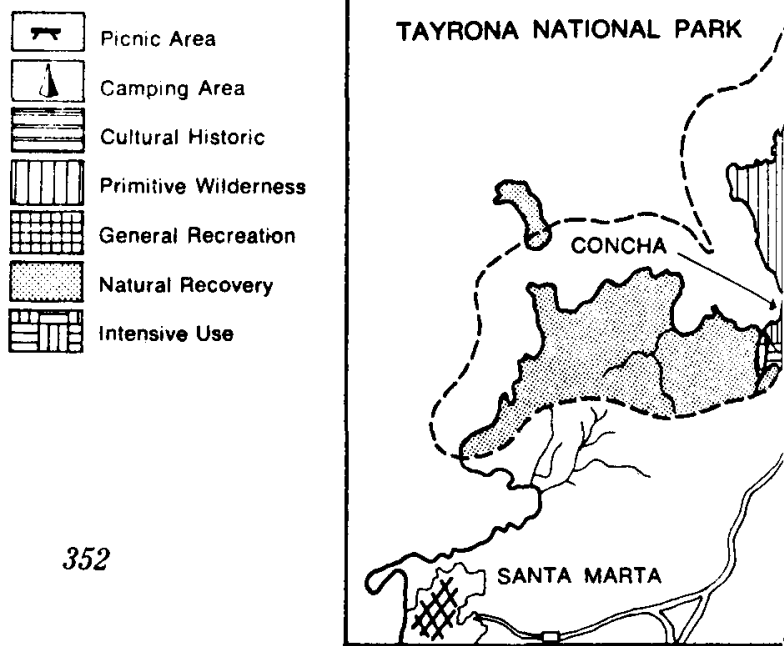
Table 1

Land Holdings in Tayrona National Park 1965-1972*

$\begin{array}{ccccc}\text { Year } & \begin{array}{c}\text { Private } \\ \text { Property Owners }\end{array} & \text { Squatters } & \text { Area Claimed } & \text { \%o of Park } \\ & 171 & 40 & 3,800 \mathrm{ha} & \text { Claimed } \\ 1965 & 86 & 32 & 2,900 \mathrm{ha} & 31.6 \% \\ 1967 & 45 & - & 1,700 \mathrm{ha} & 24.1 \% \\ 1970 & 16 & - & 600 \mathrm{ha} & 14.1 \% \\ 1972 & 15 & - & 595 \mathrm{ha} & 5.0 \% \\ 1977 & 15 & 4.9 \%\end{array}$

${ }^{\star}$ Compiled from Ruan, ${ }^{15}$ Franky, ${ }^{12}$ and Mozo, ${ }^{14}$ and from interviews with INCORA and INDERENA employees, September 1974.

+ Percentages computed on the basis of 12,000 ha.

interpretation of the Tayrona civilisation.

In 1964, to preserve this unique environment, Tayrona was given 'protected park status' and has since been managed by INDERENA, the Government agency responsible for Colombia's natural resources. An inventory taken shortly afterwards indicated that 211 people owned property within the park or simply claimed squatters' rights. This meant that 3800 ha ( 31.6 per cent) were either legally claimed or simply settled. But by early 1971, all squatters in the park, the majority of whom lived by collecting coconuts and fishing, had been removed, and 85 private holdings had been bought, giving the government control over 76 per cent of the park. By 1972, a total of 195 parcels had been acquired, leaving only 5 per cent of the park in titled properties.

But in recent years foreign tourism has become an increasingly important factor in the drive to stabilise Colombia's balance of payments. The north coast has been in a particularly difficult economic situation because of increasing numbers of rural poor crowding the coastal cities of Santa Marta, Cartagena and Barranquilla. ${ }^{20}$ In 1970, the National Tourist Corporation (CORTURISMO) was specifically charged with the development of Colombia's historic, cultural and natural resources in order to stimulate the tourist industry and attract as many foreign tourists as possible. In carrying out this mandate, CORTURISMO became involved with INDERENA in what might justifiably be called the classic example of consevation versus tourism on the South American continent.

Late in 1972 CORTURISMO decided that the best use of Tayrona's Caribbean beaches would be a multi-million-dollar tourist complex (estimated at more than $\$ 100$ million in 1978 dollars) with several 20 -storey hotels, accommodation for more than 11,000 visitors, an 18-hole golf course, two commercial centres-including restaurants, cafeterias, discotheques, taverns, cinemas and souvenir outlets - a visitor information centre and a marina. The theme was 'sun, sand and sea as a major attraction for foreign tourists ... providing the highest economic return for the country'. ${ }^{2}$ Most of the financing would be from private national and international sources, but it was necessary for the government to invest in the initial infrastructure, including expansion of the Santa Marta airport, and the sewer and water systems.

INDERENA wanted to restrict developments to those which would not compromise the park's natural values, quoting the 1971 Colombian National Park Statute which established the park zoning scheme. The Primitive Wilderness Zone, which was to 'be maintained in a natural state, with minimum alterations, conserving its primitiveness in perpetuity', ${ }^{3}$ constituted the majority of the park, and it was within this zone that CORTURISMO planned to concentrate the hotels and services (Table 2). 
Table 2

Proposed Tourist Development for Tayrona National Park.

\begin{tabular}{lcccc} 
Area & Development & No. of & \multicolumn{2}{c}{ Class } \\
& timetable & Rooms & $4-S t a r$ & $5-$ Star \\
Bahia de Cinto & $1976-1979$ & 1250 & & 1250 \\
Bahia de Nenguange & $1976-1984$ & 900 & 500 & 400 \\
Bahia de Concha & $1975-1989$ & 1900 & 1900 & \\
Arrecifes-Canaveral & $1985-1989$ & 1550 & 450 & 1100
\end{tabular}

*Compiled from information obtained from Ruan ${ }^{15}$ and CORTURISMO. ${ }^{2}$

CORTURISMO immediately came under attack. Social reformers and university students argued that the level of development proposed (four- and five-star hotels) was discriminatory because the vast majority of Colombians could never afford them. Marine biologists and other scientists claimed that irreparable damage would be done to the park's fragile coral reefs, bays and wildlife. Colombians, said one editorial, did not want 'Tayrona to be turned into another Acapulco ... where fifteen years ago its bays were submarine joys, today they are dead and populated only with beer containers, plastic bags, and other trash'.6 INDERENA pointed out that developments of this type were specifically prohibited in declared national park areas and therefore illegal.

CORTURISMO asked a private firm to assess the impact of the proposed hotel construction on the Tayrona flora and fauna, and in June 1973 the general manager of the National Tourist Corporation stated in an open editorial,

'We have researched the topic and have sufficiently explained that the type of tourist development we are proposing ... prejudices no one nor will it deteriorate in any form the ecology of the park... The Colombian government cannot allow itself the luxury of wasting these bays or not putting them into production. A developed country ... can afford to not use these parks for tourist purposes. But in our case, having such limited natural reserves, we should utilise this potential that will generate foreign income and investment.'2 17

It was also recommended that CORTURISMO could legally justify this development within a national park through implementation of a 1968 law allowing the government to declare National Tourist Resources, defined as 'public or private properties which have adequate conditions for the attraction and encouragement of tourism ... and are declared as such by the government'. ${ }^{2}$ The National Tourist Corporation had already been entrusted with several national tourist resources including the municipality of Santa Marta, adjacent to Tayrona, and would be the obvious administrator of the Tayrona tourist complex. CORTURISMO therefore proposed the removal of park status from these areas.

To achieve a rational decision called for a serious evaluation of the resource, the land use alternatives and the social costs and benefits, and a study of alternative plans, including different sites for the location of the tourist complex in the Santa Marta region and various methods of managing the park's resources without destroying them. But unfortunately each side refused to consider the other's case. Disillusioned with the 'have-have not' arguments, three newly established conservation groups - the Colombian Institute for the Conservation of Nature, the National Association for the Defence of Nature, and the Colombian Association of the Friends of National Parks - joined forces and made the future of Tayrona National Park a national heritage issue. By mid-1974, more than 50,000 Colombians had signed a petition requesting the government to 'suspend the efforts to change the natural and scientific destiny' of the park. This unprecedented show of public concern caused both President 


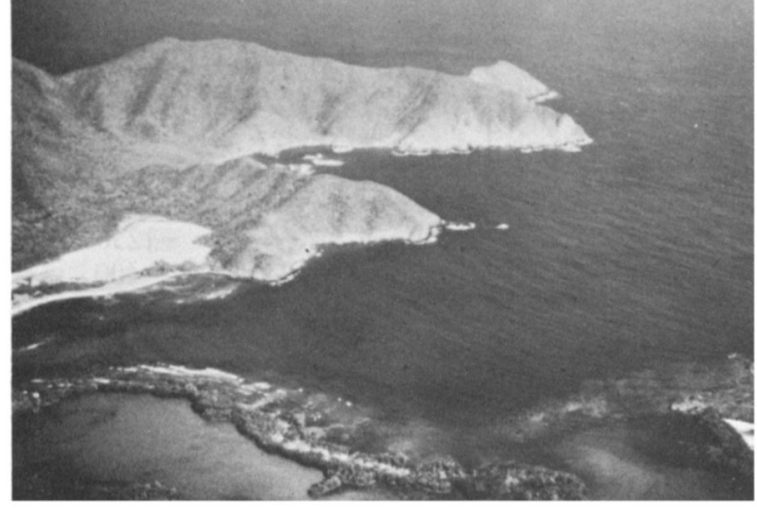

Truncated headlands near Cinto Bay

Misael Pastrana, and later his successor Alfonso Lopez Michelsen, to go on record as supporting INDERENA's efforts to preserve Tayrona. ${ }^{78}$ Radio and television stations sponsored debates and public service announcements; newspapers took editorial stands in favour of INDERENA's plan; even poorer segments of the population responded, rallying support for the 195 small farmers who had sold their holdings within Tayrona to the federal government under the assumption that their land was to be preserved as a park and not developed as a tourist centre, whereas under the CORTURISMO plan, only the rich, who had refused to sell to INDERENA, would profit from the increased land values.

In an address after inauguration, in August 1974, President Alfonso Lopez Michelsen spoke of the need for a comprehensive environmental law for Colombia, and publicly acknowledged the grassroots efforts of conservationists, saying that the Tayrona issue had advanced from one of agency politics to one of national concern:

Tayrona National Park has become a symbol of Colombia's continuing commitment to the preservation and proper management of important resources for both present day and future citizens. We must not haphazardly plan irreplaceable resources. Colombians from every walk of life must have input into this decision. ${ }^{8}$

When, in January 1975, the Colombian Congress passed the National Environmental Code ${ }^{4}$ prohibiting any change in nomenclature once a park has been established, INDERENA's position was noticeably strengthened. Tayrona could not be declared a National Tourist Resource. Support came from both Colombian and foreign scientists. The Colombian Academy of Science felt that even limited development would result in the loss of United Nations recognition of the park. It is prestigious for Colombia that six of its ten national parks have met the requirements for inclusion in the IUCN List, but to maintain this position, they must continue to be areas 'where visitors are allowed to enter under special conditions for inspirational, educational, cultural and recreational values ... and where residential, commercial or industrial occupation is prohibited. 13

Moreover, CORTURISMO had not conducted the necessary cost-benefit studies to substantiate the claim that the investments and economic return would outweigh on a long-term basis the values which a national natural park could provide. Experience in the Caribbean tourist industry of the sort of development proposed for Tayrona shows a short life of approximately 20 years after which the capital begins to decline quickly in value. If after this period the demand from international tourism declined, Colombia could be trying to maintain tourist interest with outdated facilities that had been abandoned by foreign financiers, and most importantly, with resources that might have been 
This decision may signal a new conservation awareness in Latin America; it has already been cited by the Venezuelan Government in defence of its Morrocoy National Park, also on the Caribbean coast. Colombia still has significant national park management problems, ${ }^{18}{ }^{19}$ but the positive steps taken in the Tayrona case towards habitat preservation deserve wide recognition.

\section{References}

1. CIARDELLI, ALEJANDRO 1967. Parque nacional de los Tayronas. CVMHarvard University. Archivo de parques nacionales, INDERENA. Bogotá, Colombia.

2. COLOMBIA, CORPORACION NACIONAL DE TURISMO (CORTURISMO) 1972. Parque nacional natural de Santa Marta, diagnostico y plan turistico. Biblioteca, INDERENA. Bogotá.

3. COLOMBIA, INSTITUTO DE DESARROLLO DE LOS RECURSOS NATURALES RENOVABLES (INDERENA) 1971. Acuerdo No. 42, estatuto de las reservaciones del sistema de parques nacionales. Archivo de parques nacionales, INDERENA. Bogotá.

4. COLOMBIA, SECRETARIA GENERAL DEL MINISTERIO DE GOBIERNO 1975. Diaro Oficial, Lunes 27 Enero. Bogotá.

5. DOLMATOFF, GERARDO, and ALICIA DOLMATOFF 1961. The people of Aritama: the cultural personality of a Colombian village. The University of Chicago Press.

6. EL TIEMPO 1972. Acapulco y el caso Tayrona. Editorial, Sept. 20. Bogotá.

7. 1974a. Grupo asesor de Lopez Apoya parque Tayrona. Editorial, March 20. Bogotá.

8. 1974b. Defender al Tayrona piden el Presidente. Editorial, March 25. Bogotá.

9. 1976. Excluido el Tayrona de Plan Turistico. March 29. Bogotá.

10. FITTER, RICHARD 1974. Most endangered mammals; an action programme. Oryx 12: 436-449.

11. FRANKY, SIMON MAX 1971. Parques nacionales Colombianos de la costa Atlantica. Congreso nacional Colombiano sobre recursos naturales, Doc. No. 122. Biblioteca, INDERENA.

12. y PEDRO RODRIGUEZ 1967. Estudio de tenencia y uso de la terra, parque nacional Santa Marta (Tayrona). Biblioteca, INDERENA. Bogotá.

13. IUCN 1974. United Nations List of National Parks and Equivalent Reserves. New Series Pub. No. 29. Morges, Switzerland.

14. MOZO, TEOBALDO MORRON 1971. Los parques nacionales y la reforma agraria. VII reunion del comite Latinoamericano de parques nacionales (CLAPN). Medellin, Colombia.

15. RUAN RUAN, FERNANDO, X y SIMON MAX FRANKY 1972. El parque Tayrona para Colombia. Archivo de parques nacionales, INDERENA. Bogotá.

16. SARMIENTO PENA, JOSE 1971. El parque nacional Tayrona y turismo. CLAPN. Medellin, Colombia.

17. SOLOMON, GAIL 1973. Why gild an emerald coast? Sierra Club Bulletin, January: 23-25.

18. STRUHSAKER, THOMAS T. 1976. The dim future of La Macarena. Oryx 13: 298-302.

19. WETTERBERG, GARY B., and RICHARD A. MEGANCK 1976. Colombia's national parks and related reserves: an analysis of research needs and management. Proc. XXIII International Geographical Union Meeting. Moscow.

20. WORLD BANK-INTERNATIONAL DEVELOPMENT ASSOCIATION 1973. Annual Report. Washington, DC. 